\title{
Spatial Distribution of Lichens in Metrosideros excelsa in Northern New Zealand Urban Forests
}

\author{
Gladys N. Benitez ${ }^{1, *}$, Glenn D. Aguilar ${ }^{2}\left(\mathbb{D}\right.$ and Dan Blanchon ${ }^{2}$ \\ 1 School of Environmental Sciences, Universidad Ana G Mendez, P.O. Box 3030 Gurabo, \\ Gurabo 00778-3030, Puerto Rico \\ 2 School of Environmental and Animal Sciences, Unitec Institute of Technology, Private Bag 92025, \\ Auckland 1025, New Zealand; gaguilar@unitec.ac.nz (G.D.A.); dblanchon@unitec.ac.nz (D.B.) \\ * Correspondence: gbenitez3@email.uagm.edu
}

Citation: Benitez, G.N.; Aguilar,

G.D.; Blanchon, D. Spatial

Distribution of Lichens in

Metrosideros excelsa in Northern

New Zealand Urban Forests.

Diversity 2021, 13, 170. https://

doi.org/10.3390/d13040170

Academic Editors: Ana Pintado and Michael Wink

Received: 26 March 2021

Accepted: 9 April 2021

Published: 16 April 2021

Publisher's Note: MDPI stays neutral with regard to jurisdictional claims in published maps and institutional affiliations.

Copyright: (c) 2021 by the authors. Licensee MDPI, Basel, Switzerland. This article is an open access article distributed under the terms and conditions of the Creative Commons Attribution (CC BY) license (https:// creativecommons.org/licenses/by/ $4.0 /)$.

\begin{abstract}
The spatial distribution of corticolous lichens on the iconic New Zealand pōhutukawa (Metrosideros excelsa) tree was investigated from a survey of urban parks and forests across the city of Auckland in the North Island of New Zealand. Lichens were identified from ten randomly selected trees at 20 sampling sites, with 10 sites classified as coastal and another 10 as inland sites. Lichen data were correlated with distance from sea, distance from major roads, distance from native forests, mean tree DBH (diameter at breast height) and the seven-year average of measured $\mathrm{NO}_{2}$ over the area. A total of 33 lichen species were found with coastal sites harboring significantly higher average lichen species per tree as well as higher site species richness. We found mild hotspots in two sites for average lichen species per tree and another two separate sites for species richness, with all hotspots at the coast. A positive correlation between lichen species richness and DBH was found. Sites in coastal locations were more similar to each other in terms of lichen community composition than they were to adjacent inland sites and some species were only found at coastal sites. The average number of lichen species per tree was negatively correlated with distance from the coast, suggesting that the characteristic lichen flora found on pōhutukawa may be reliant on coastal microclimates. There were no correlations with distance from major roads, and a slight positive correlation between $\mathrm{NO}_{2}$ levels and average lichen species per tree.
\end{abstract}

Keywords: Metrosideros excelsa; lichens; New Zealand; hotspots; indicators; Auckland

\section{Introduction}

Patterns in epiphytic lichen community composition and species distribution are generally considered to be a result of the interaction between environmental factors, habitat quality and quantity, habitat continuity and the ability of individual lichen species to successfully disperse [1-3]. Environmental factors such as temperature, rainfall, sunshine hours, aspect, altitude, latitude and distance from the coastline have been identified as important [4-6]. Habitat quality can include factors such as presence of particular tree species if some lichen species have preferred substrates, tree size, tree age, bark texture and $\mathrm{pH}$, or presence of holes and cracks [7-14]. Diameter of the tree at breast height (DBH) is often used as a proxy for tree size [15] or age [16] and has been positively correlated with lichen species richness in mangrove forests in New Zealand [6], Mediterranean oak forests [4] and deciduous forests in Sweden [17].

Epiphytic lichen species have differing abilities to disperse due to their ability to produce appropriate propagules (sexual or asexual) and have specific habitat requirements for successful colonization and establishment. Some species have low dispersal ability [18-21]. For these species, habitat connectedness and habitat continuity through time may be critical factors predicting their presence and absence at the landscape scale $[7,8,22,23]$. Other species are favored in fragmented or disturbed sites [24], or may be tolerant of air pollution $[22,23,25,26]$, and tend to be more widely distributed. 
Urbanization significantly alters vegetation patterns, usually resulting in reduced, fragmented or disconnected forest areas [27]. Urban sites present challenges for epiphytic species as these often have specialized microclimate requirements. Canopy removal, the simplified vegetation structures of planted vegetation and physical proximity to urban heat islands caused by increased proportions of impermeable surfaces all contribute to the creation of "edge" habitats with higher light levels, fluctuating temperatures, and lower humidity and soil moisture levels [28-30]. The presence of original native forest remnants may be critical as a source of lichen propagules for some species [9]. The absence of suitable phorophyte tree species, or trees of a suitable age, size or architecture, will also potentially limit which epiphyte species will be present [31,32]. In addition, urban air pollutants such as sulphur dioxide $\left(\mathrm{SO}_{2}\right)$, ammonia $\left(\mathrm{NH}_{3}\right)$ and nitrogen oxides $\left(\mathrm{NO}_{\mathrm{x}}\right)$ are known to negatively affect epiphytes, particularly lichens [33,34], although some lichens are nitrophytes and may be favoured by higher levels of $\mathrm{NH}_{3}$ or $\mathrm{NO}_{x}[26,35]$. As a result of all of this, urban epiphyte communities tend to be dominated by pollution-tolerant pioneer species [34].

Efforts are underway world-wide to reverse the loss of urban forest ecosystems, with a focus on preserving or enhancing natural forest remnants or planting new ones [27,36,37]. The process usually begins with the removal of invasive species and the planting of native pioneer tree species with the end goal of developing a mature forest that is able to support a diverse range of species including epiphytes [38]. As noted earlier, the colonization, survival and succession of epiphytes in urban forests are controlled by vegetation patterns [27], environmental factors [28-30] and substrate suitability [31]. The rate of colonization is usually low [39], and urban forests may not have the same epiphyte assemblage as natural forest [40].

New Zealand was largely covered in forest prior to the arrival of humans c. 1000 ago, but this has been reduced to ca. $23 \%$ as a result of large-scale land clearances by Mãori and Europeans [41]. The effects on the largely urbanized Auckland region have been greater still, with a reduction from $93 \%$ forest cover to $13 \%$. A large number of ecological restoration projects are underway across the region in an attempt to reestablish or augment existing forest remnants [42]. Auckland's Urban Ngahere (Forest) Strategy [43] commits to increasing forest cover for the region, with a preference for indigenous tree species. Planting is done within an ecological/landscape matrix of declining native vegetation remnants, highly modified landscapes and exotic and native planting in parks, gardens and roadsides [42-45].

As is the case elsewhere, ecological restoration projects in Auckland do not usually include lichens, bryophytes, fungi, or other epiphytes and there is the assumption that they will naturally colonize the trees and shrubs being planted $[46,47]$. It has been reported that planting native trees within a landscape can assist in the maintenance of lichen diversity [23], but is not known if lichen assemblages characteristic of particular forest types or tree species form in planted sites or if a smaller subset of photophilous urban lichen species are present instead. There is little information available on the characteristic lichen mycobiotas of native tree species in New Zealand. One tree species, pōhutukawa (Metrosideros excelsa Sol. Ex Gaertn.), has a reasonably well-known lichen mycobiota [48], is planted widely in restoration projects, parks and gardens, and is present in naturally occurring coastal forest remnants, making this an ideal species for a study examining the factors influencing the formation of lichen communities in the Auckland Region. In addition, pōhutukawa is under severe threat from the arrival of myrtle rust (Austropuccinia psidii (G. Winter) Beenken) $[49,50]$ making the collection of data about its associated species critical. In this study, we present information on the species composition, richness and spatial characteristics of lichens present in 20 sampling sites in the Auckland Region in New Zealand to examine whether planted pōhutukawa in a range of ecological settings can host specific lichen assemblages, and whether this is influenced by habitat quality, anthropogenic pressures or other environmental factors. 


\section{Materials and Methods}

\subsection{Sampling Sites and Environmental Variables}

A preliminary survey of the sampling sites was conducted to identify common species of native trees that had abundant cover with different species of lichens. After visiting the sites, pōhutukawa tree was chosen as the host tree species to monitor for lichens. Metrosideros excelsa is an endemic angiosperm evergreen tree that is common in the coastal areas of northern New Zealand and has readily available data on lichen associates [48,51]. Sampling sites were selected based on geographic spread and accessibility and consisted mainly of reserves and parks in Auckland, New Zealand. These parks and reserves also include protected natural lands, ecological reserves, wetlands, and other green areas that are designated to provide healthy habitats for humans, wildlife and plants in densely built cities. Ten sampling sites were allocated near the coast and another ten selected from inland reserves or parks. Sites were considered coastal if the centroid of the sample site of ten trees was less than $300 \mathrm{~m}$ from the nearest coastline. Sites 10,11, 12 and 17 are within naturally occurring coastal forest. Distances from the centroid of the sampling site to the major roads and original forest stands (i.e., naturally occurring forested remnants, largely consisting of native tree species) were also measured to determine relationships with lichen species richness. (Table 1 and Figure 1). To determine the influence of pollutants on lichen distribution, available Nitrous dioxide $\left(\mathrm{NO}_{2}\right)$ data from monitoring stations of the New Zealand Transport Agency were downloaded and processed to generate a raster surface representation that allowed an interpolation of the $\mathrm{NO}_{2}$ values at each lichen site [52-54].

Table 1. Lichen sampling sites in Auckland, New Zealand and their classification.

\begin{tabular}{ccc}
\hline No. & Site Name & Classification \\
\hline 1 & Jaggers Bush & Inland \\
2 & Western Springs & Inland \\
3 & Waiatarua Reserve & Inland \\
4 & Cranwell Park & Inland \\
5 & Oakley Creek Unitec & Inland \\
6 & Mount Albert & Inland \\
7 & Roy Clements Tree Walk & Inland \\
8 & Coyle Park & Coastal \\
9 & Eric Armishaw Walkway & Coastal \\
10 & Blockhouse Bay & Coastal \\
11 & Green Bay & Coastal \\
12 & Kingswood Reserve & Coastal \\
13 & Tony Segedin Reserve & Coastal \\
14 & Tahaki Reserve & Inland \\
15 & Cornwall Park & Inland \\
16 & Auckland Domain & Inland \\
17 & Murrays Bay & Coastal \\
18 & Long Bay & Coastal \\
19 & Devonport & Coastal \\
20 & Tamaki Drive & Coastal \\
\hline
\end{tabular}




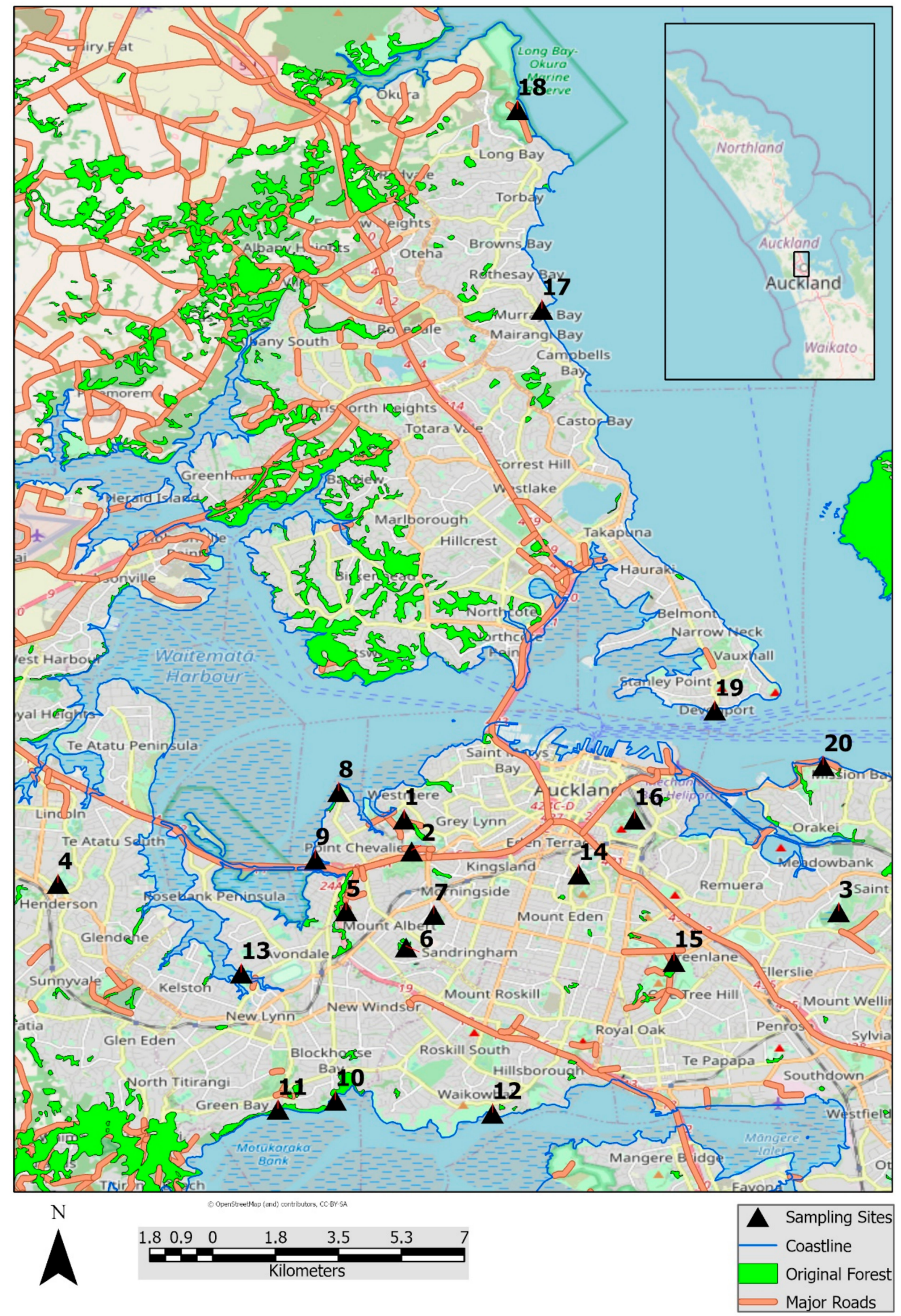

Figure 1. Sampling sites in Auckland, New Zealand with native forest stands, roads and coastline. 


\subsection{Data Collection}

Field work was carried during the months of June and July of 2017. Ten M. excelsa trees with DBH (diameter at breast height) values greater than $8.5 \mathrm{~cm}$ were randomly selected from each site. Due to the tendency of most Pōhutukawa to have several main trunks from the roots, the DBH measured in this case was the total outside diameter of the largest trunk at a height of $1 \mathrm{~m}$ from the ground. For each tree, all lichen species $1 \mathrm{~m}$ to $2 \mathrm{~m}$ from the ground along the tree circumference were identified and recorded. When the identification was not possible in the field, samples were collected and taken to the Unitec herbarium (UNITEC) for identification. Nomenclature follows the species recognized in the most recent conservation threat listing for New Zealand lichens [48].

\subsection{Data Analysis}

The average species count per tree for each site and the total number of species for each site were used as dependent variables in the geostatistical tools included in ArcMap 10.7 [55]. Tools used include the Hotspot Analysis or the Getis-Ord Gi* statistic [14,56-58] for determining sites with significantly higher values or lower values. The output of Hotspot Analysis is a map showing the levels of significance of the $z$-value of the Getis-Ord Gi* statistic at confidence values of $90 \%, 95 \%$ and $99 \%$. The different values of confidence levels provide an enhanced visualization of the lichen distribution in terms of the dependent variables indicating the relative strength of the hotspot, additional information that is not available when only one confidence value is pre-selected. Another geostatistical tool, Cluster and Analysis/ Anselin Local Moran I [59-61] was used for characterizing the sampling neighborhood to indicate whether there is a significant relationship in terms of the values of neighboring sites. The output of the Anselin Local Moran tool shows sites with significant values classified in terms of Cluster-Outlier Type (COType) describing sites of high value surrounded by sites of high value (HH), high value with low value (HL), low value with high value (LH) and low value surrounded by low value (LL). Prior to the analysis, the global Moran's I statistics was run to determine if spatial autocorrelation exists in the data [16,58,62]. Results of Moran's I statistics also determine some of the options in running the geostatistics tools [63].

The OLS (Ordinary Least Squares) Tool in ArcMap [64,65] was used to determine the significance of the relation between the average lichen species per tree for each site and total species per site dependent variables, with the average $\mathrm{DBH}$, distance from the coastline, distance from roads, distance from original forests and average $\mathrm{NO}_{2}$ concentration from 2010 to 2016. OLS results in regression coefficients that describe the relationship between dependent and explanatory variables and provides values of significance of the coefficients. Several statistical measures also indicate overall model significance (Joint $\mathrm{F}$ and Wald Statistics), multi-collinearity (indicated by the large Variance Inflation Factor (VIF); if more than 7.5, there is redundancy in the variables), spatial autocorrelation (Moran's I and Koenker Statistic), heteroscedasticity or inconsistent residual variance (Koenker Statistic), normal distribution of residuals (Jarque-Bera Statistic) and non-stationarity or regional variance (Koenker Statistic). To compare lichen values between the inland and coastal locations, the non-parametric Mann-Whitney U test was used.

\section{Results}

\subsection{Species Counts}

Thirty-three lichen species, belonging to 22 genera, with one unknown species were recorded in the 20 sites. Sixteen species were found in both inland and coastal sites, thirteen species were found only in the coastal sites and five species were found only in the inland sites. A total of 915 lichen individuals were counted with Parmotrema reticulatum, Dirinaria applanata and Chrysothrix xanthina comprising $14.86 \%, 14.32 \%$ and $12.13 \%$ of the total individual occurrences, respectively. Parmotrema reticulatum was found at all of the sampled sites, while Dirinaria applanata and Chrysothrix xanthina were found at 18 and 17 sites, respectively. Nine species were found with only one occurrence (Table 2). 
Table 2. Count of species with the number of sites at which they were found.

\begin{tabular}{|c|c|c|c|}
\hline No & Species & $\begin{array}{c}\text { Occurrences } \\
\text { (out of } 200 \text { Trees) }\end{array}$ & $\begin{array}{l}\text { Sites } \\
\text { Found }\end{array}$ \\
\hline 2 & Parmotrema reticulatum (Taylor) M.Choisy & 136 & 20 \\
\hline 1 & Dirinaria applanata (Fée) Awasthi & 131 & 18 \\
\hline 6 & Chrysothrix xanthina (Vain.) Kalb & 111 & 17 \\
\hline 10 & Punctelia subrudecta (Nyl.) Krog & 74 & 13 \\
\hline 14 & Parmotrema perlatum (Huds.) M.Choisy & 69 & 12 \\
\hline 18 & Lepraria finkii (B. de Lesd.) R.C.Harris & 69 & 12 \\
\hline 3 & Graphis elegans (Sm.) Ach. & 66 & 14 \\
\hline 4 & Usnea rubicunda Stirt. & 62 & 17 \\
\hline 12 & Heterodermia speciosa (Wulfen) Trevis. & 45 & 9 \\
\hline 13 & Flavoparmelia haywardiana Elix \& J.Johnst. & 25 & 6 \\
\hline 15 & Physcia poncinsii Hue & 18 & 5 \\
\hline 11 & Ramalina celastri (Spreng.) Krog et Swinscow & 17 & 7 \\
\hline 20 & Parmotrema robustum (Degel.) Hale & 14 & 4 \\
\hline 25 & Parmotrema mellissii (C.W.Dodge) Hale & 11 & 2 \\
\hline 30 & Lecanora elatinoides Räsänen & 9 & 4 \\
\hline 7 & Xanthoria parietina (L.) Th.Fr & 7 & 6 \\
\hline 26 & Parmotrema austrocetratum Elix \& J.Johnst. & 7 & 2 \\
\hline 16 & Pertusaria thiospoda C.Knight & 6 & 3 \\
\hline 19 & Pyxine subcinerea Stirt. & 6 & 3 \\
\hline 27 & Sticta martinii D.J.Galloway & 6 & 2 \\
\hline 5 & Coenogonium luteum (Dicks.) Kalb \& Lücking & 5 & 2 \\
\hline 9 & Polyblastidium casarettianum (A.Massal.) Kalb & 4 & 2 \\
\hline 24 & Enterographa pallidella (Nyl.) Redinger & 4 & 3 \\
\hline 33 & Lecanora subumbrina Müll.Arg. & 3 & 2 \\
\hline 8 & Bacidia laurocerasi (Delise ex Duby) Vain. & 2 & 1 \\
\hline 17 & Unknown & 1 & 1 \\
\hline 21 & Lecania cyrtella (Ach.) Th.Fr. & 1 & 1 \\
\hline 22 & Bacidia wellingtonii D.J.Galloway & 1 & 1 \\
\hline 23 & Arthonia atra (Pers.) A.Schneid. & 1 & 1 \\
\hline 28 & Thalloloma subvelata (Stirt.) D.J.Galloway & 1 & 1 \\
\hline 29 & Parmotrema crinitum (Ach.) M.Choisy & 1 & 1 \\
\hline 31 & Lecanactis neozelandica Egea \& Torrente & 1 & 1 \\
\hline 32 & Opegrapha agelaeoides Nyl. & 1 & 1 \\
\hline
\end{tabular}

Results of interpolating the values of $\mathrm{NO}_{2}$ from the raster surface derived from the values recorded by the NZTA (New Zealand Transport Agency) stations in Auckland shows a mean of $28.52 \mu \mathrm{g} \mathrm{m}^{-3}$ (SE = 1.303) from 2010 to 2016 for the sites sampled (Figure 2). 


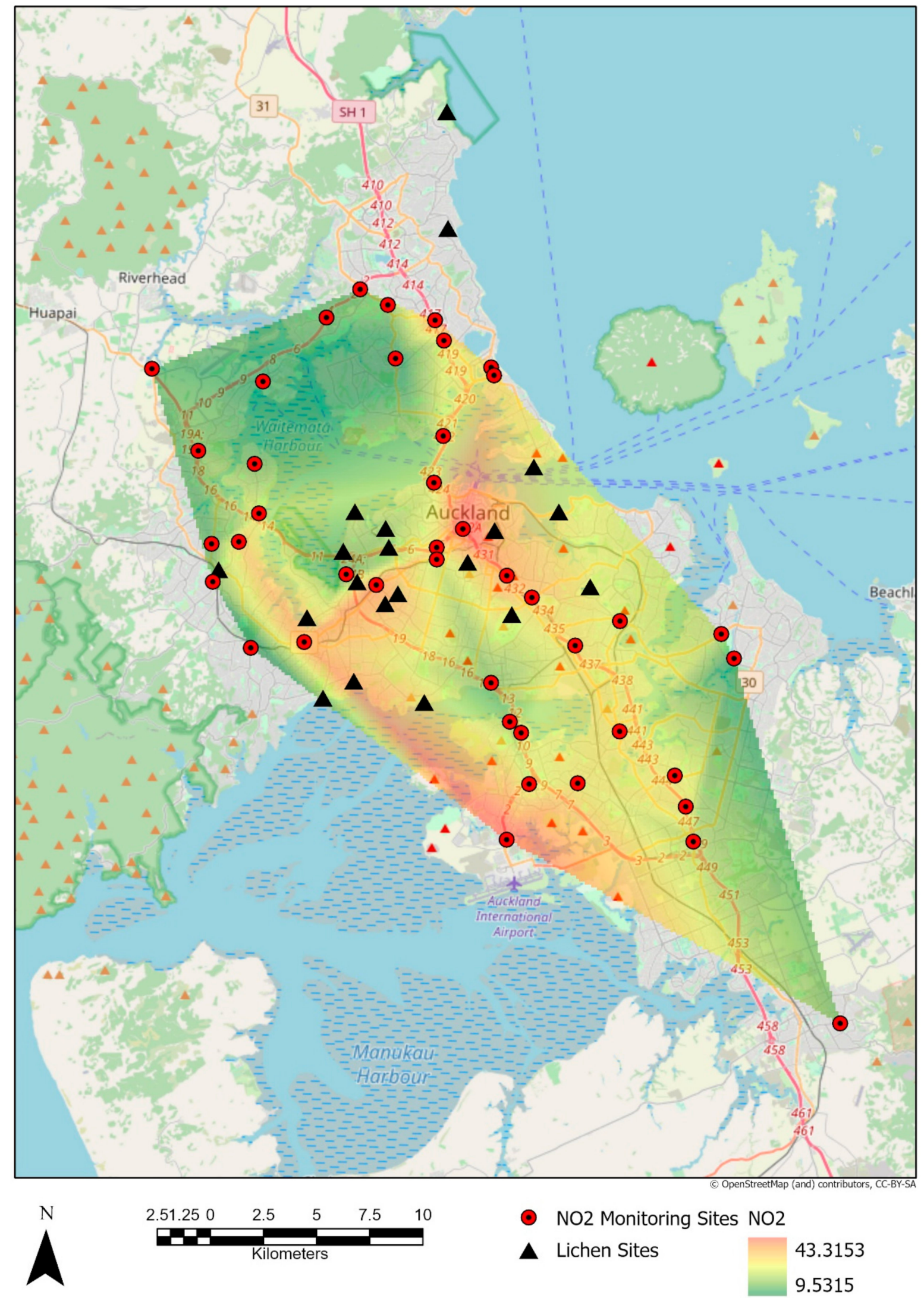

Figure 2. Nitrous dioxide $\left(\mathrm{NO}_{2}\right)$ raster surface derived from the mean of 2010-2016 monitored values in $\mu \mathrm{g} \mathrm{m} \mathrm{m}^{-3}$. 
An average of 4.68 species per tree $(\mathrm{SE}=0.343)$ and an average of $9.7(\mathrm{SE}=0.949)$ species per site was determined from all the samples taken. Average DBH was $101.95 \mathrm{~cm}$ ( $\mathrm{SE}=9.916)$ (Table 3 , average distance of the centroid of the sampling site from the coast was $902.43 \mathrm{~m}(\mathrm{SE}=235.6100)$, average distance from roads was $810.44 \mathrm{~m}(\mathrm{SE}=149.962)$ and average distance to the nearest native forest was $581.46 \mathrm{~m}(\mathrm{SE}=135.322)$. The highest numbers of species were found in the coastal sites of Blockhouse Bay (Site 10) and Murrays Bay (Site 17), and one inland site-Oakley Creek Unitec (Site 5) (Table 2).

Table 3. Results of lichen data sampling and values of the variables for each site.

\begin{tabular}{|c|c|c|c|c|c|c|c|}
\hline Site & $\begin{array}{l}\text { Species/Tree } \\
\text { Ave. }\end{array}$ & $\begin{array}{c}\text { Total } \\
\text { Species/Site }\end{array}$ & $\begin{array}{l}\text { DBH Ave. } \\
\text { (cm) }\end{array}$ & $\begin{array}{l}\text { Coast Dist. } \\
(\mathrm{m})\end{array}$ & $\begin{array}{l}\text { Roads Dist. } \\
\text { (m) }\end{array}$ & $\begin{array}{l}\text { Original Forest } \\
\text { Dist. (m) }\end{array}$ & $\begin{array}{c}\mathrm{NO}_{2} \text { Ave. } 2010-2016 \\
\left(\mu \mathrm{g} / \mathrm{m}^{3}\right)\end{array}$ \\
\hline 1 & 2.30 & 4 & 12.58 & 305.12 & 164.17 & 194.23 & 22.13 \\
\hline 2 & 3.30 & 5 & 112.74 & 762.76 & 33.86 & 358.97 & 22.48 \\
\hline 3 & 2.20 & 3 & 23.41 & 1240.32 & 578.89 & 1389.31 & 28.28 \\
\hline 4 & 2.00 & 4 & 39.86 & 1989.83 & 1493.82 & 560.46 & 21.37 \\
\hline 5 & 4.60 & 16 & 62.95 & 810.02 & 52.98 & 131.63 & 26.29 \\
\hline 6 & 4.75 & 7 & 130.81 & 2318.48 & 1468.32 & 0.00 & 35.57 \\
\hline 7 & 3.50 & 6 & 83.98 & 2405.05 & 1805.70 & 604.20 & 34.18 \\
\hline 8 & 5.00 & 9 & 98.82 & 7.11 & 1153.78 & 239.73 & 24.88 \\
\hline 9 & 4.60 & 9 & 113.57 & 54.32 & 272.90 & 839.52 & 30.31 \\
\hline 10 & 6.50 & 16 & 122.77 & 288.99 & 1207.91 & 0.00 & 36.58 \\
\hline 11 & 5.75 & 13 & 69.79 & 69.66 & 355.55 & 0.00 & 21.17 \\
\hline 12 & 4.33 & 10 & 81.21 & 27.86 & 2081.97 & 175.11 & 30.77 \\
\hline 13 & 8.50 & 13 & 135.99 & 34.78 & 355.43 & 673.66 & 31.86 \\
\hline 14 & 4.83 & 10 & 92.36 & 2468.29 & 767.38 & 697.92 & 32.23 \\
\hline 15 & 4.40 & 6 & 127.77 & 3429.34 & 66.44 & 0.00 & 29.68 \\
\hline 16 & 5.75 & 12 & 169.71 & 1120.35 & 713.05 & 580.01 & 37.02 \\
\hline 17 & 5.57 & 16 & 108.42 & 92.37 & 1851.02 & 601.14 & - \\
\hline 18 & 5.50 & 15 & 136.20 & 53.71 & 89.45 & 1532.80 & - \\
\hline 19 & 5.29 & 10 & 173.89 & 72.09 & 1195.40 & 2389.34 & 29.82 \\
\hline 20 & 4.85 & 10 & 142.22 & 98.17 & 500.74 & 661.19 & 28.84 \\
\hline
\end{tabular}

Note: Lichen stations 17 and 18 were not covered by the resulting $\mathrm{NO}_{2}$ calculated surface.

A map depicting the number of species per tree for all the 20 sites sampled is shown in Figure 3. The lowest number of average species counts is at the inland site Waiatarua (Site 3), Jaggers Bush (Site 1), and Cranwell Park (Site 4), where the pōhutukawa trees have the lowest average $\mathrm{DBH}$. 

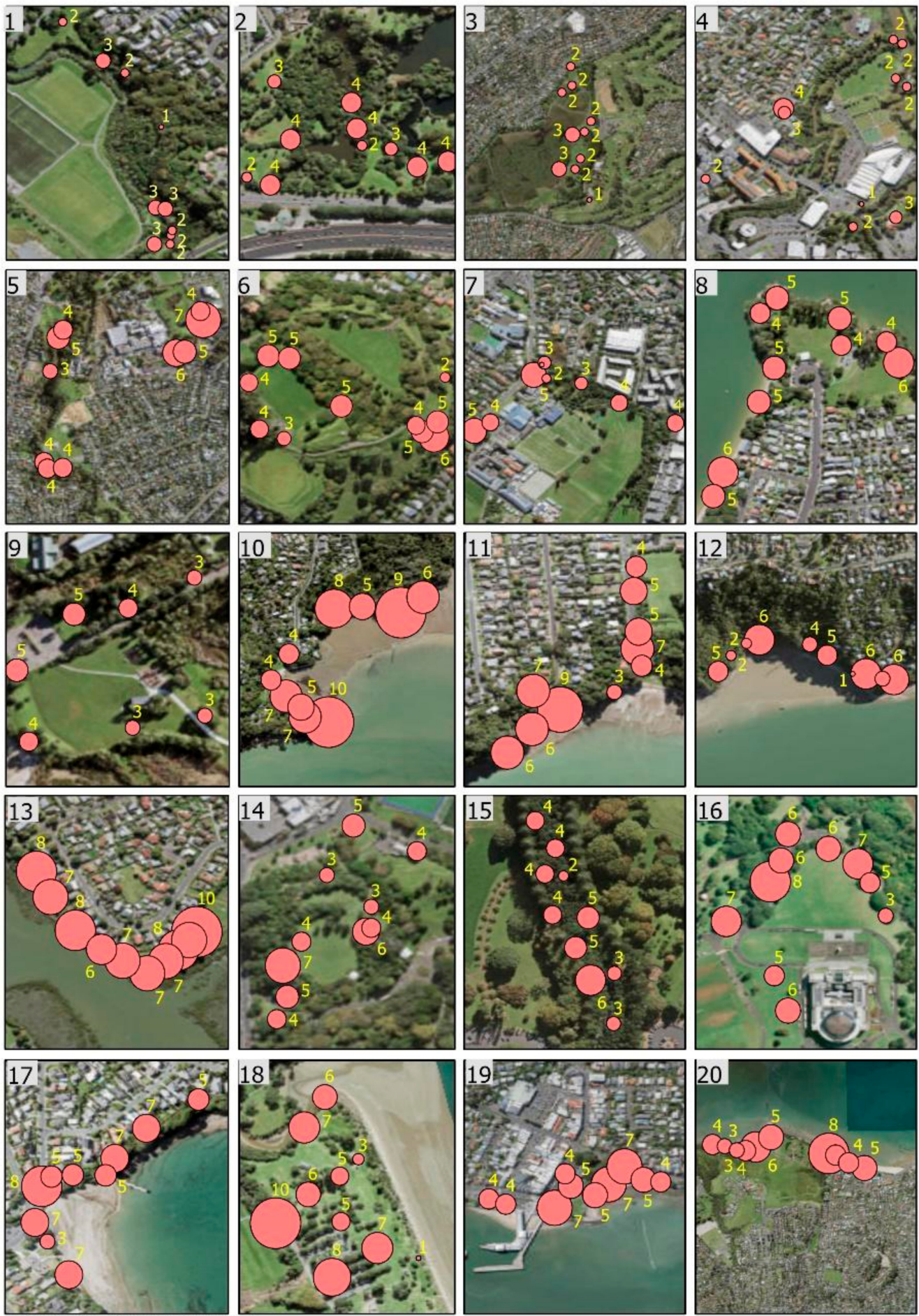

Figure 3. Lichen species count per tree from the 20 sampling sites.

\subsection{Results of Geostatistical Analysis}

Results from the Moran's I correlation coefficient showed the absence of spatial autocorrelation (z-score $=-0.456009 ; p$-value $=0.648384)$ for the average number of species per tree and for the total number of species per site; the Moran's I also showed no spatial autocorrelation $(\mathrm{z}$-score $=1.448871 ; p$-value $=0.147347)$. This absence of spatial autocorrelation provides confidence in using the Hotspot and Cluster and Outlier analysis geostatistical tools. 
Hotspot analysis identified a hot spot with a confidence level at $90 \%$ for the average lichen per tree in the Blockhouse Bay (Site 10) and Green Bay (Site 11) sites and a 90\% cold spot at Waiatarua Reserve (Site 3). For the total number of species, hotspots $(90 \%$ confidence) for total number of species were found in Long Bay (Site 18) and Murrays Bay (Site 17), while a coldspot (95\% confidence) is shown at Waiatarua Reserve. Cluster and Outlier analysis shows a significant Low-High Outlier result at Cranwell Park (Site 4) (Figure 4).

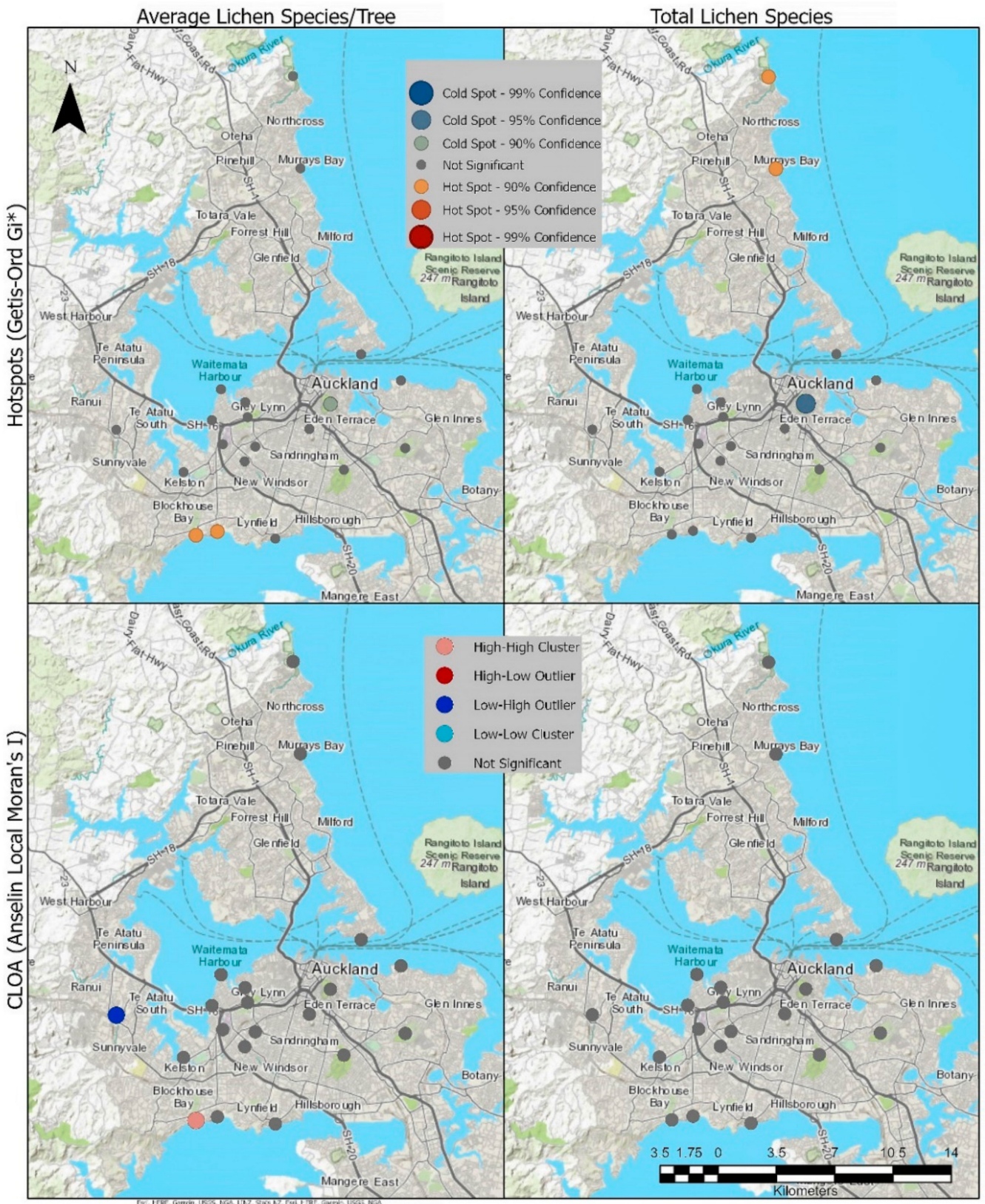

Figure 4. Hotspots and Cluster and Outlier Analysis (COTypes) for average species per tree and total species count of the survey sites.

Results of OLS show that the dependent variable Average Lichen Species per tree has significant negative coefficient with Distance from Coast (coefficient $=-0.000554 ; p$-value $=0.033$ ), significant positive coefficient with Average tree DBH (coefficient $=0.016590$; $p$-value $=0.001$ ) and significant negative coefficient with Distance from Original Forest (coefficient $=-0.000743 ; p$-value $=0.035398$ ), while Distance from Roads does not show significant coefficients. The variable $\mathrm{NO}_{2}$ showed a slight significant positive coefficient 
(coefficient $=0.125501 ; p$-value $=0.071467)$. This OLS model has a VIF-Variance Inflation Factor from 1.008 to 1.056 , much less than 7.5 and an indication that there is no redundancy among the variables. Significant values of the Joint-F statistic ( $p$-value $=0.013)$ and the Joint Wald statistic ( $p$-value $=0.000)$ indicate overall model significance. Both the Koenkerr $(\mathrm{BP})$ statistic $(p$-value $=0.311)$ and the Janque-Bera statistic $(p$-value $=0.768)$ are not significant, indicating consistency in the relationships and absence of bias in model predictions.

For the variable Total Species, the Distance from Coast, Average DBH, Distance from Roads and average $\mathrm{NO}_{2}$ showed no significant coefficient, while a significant coefficient was observed with Distance from Original Forest $\left(p\right.$-value $\left.=0.001512^{*}\right)$. This model result was supported by the Joint Ward statistic $(p$-value $=0.020947)$ that indicates overall model significance. The model was also found to have a consistent relationship as indicated by the Koenkerr $(\mathrm{BP})$ statistic $(p$-value $=0.378)$, and the absence of bias as shown by the Janque-Bera statistic $(p$-value $=0.377)$.

\subsection{Comparison between Inland and Coastal Sites}

For the Average Species per Tree comparison between coastal and inland sites, a significant difference is found from the Mann-Whitney $U$ test $(U=14.5$; $z$-score $=2.65$; $p$-value $=0.004)$. The relationship for the Total Species is no different from the former with the Mann-Whitney $U$ test returning identical values $(U=17.5$; $\mathrm{z}$-score $=2.43$; $p$-value $=0.007)$.

\section{Discussion}

The total of thirty-three lichen species is a relatively small subset of the 187 species and lower ranks recorded to date from this tree species [48]. This is not altogether surprising as the sampling sites in this study are from a moderately to highly modified region within the natural range of pōhutukawa, while the study of Blanchon et al. [48] covered much of the full natural range (the upper North Island and offshore islands). In addition, our study did not sample from the upper canopy of trees, reducing the likelihood of collecting photophilous species of Ramalina and Usnea. A similar result for urban sites was found in a study of lichen diversity in mangrove forest (Avicennia marina subsp. australasica) in New Zealand [6].

Lichen species counts in terms of average lichens per tree and the total number of lichens per site from the 20 sites showed differences between sites identified as coastal and inland. Of the 33 species identified, 29 (85\%) of the species recorded were found in the coastal sites versus $13(39 \%)$ in the inland sites, demonstrating higher richness and diversity in coastal sites. Four species (Chrysothrix xanthina, Dirinaria applanata, Parmotrema reticulatum and Usnea rubicunda) were found at most or all of the study sites. These species are common photophilous urban lichens. Other species, such as Enterographa pallidella, Parmotrema austrocetratum, P. mellissii, P. robustum, and Sticta martinii, are not commonly encountered in inland urban vegetation and may in fact be pōhutukawa or coastal forest lichen species.

The hotspots for the highest number of lichen species per tree were found at Blockhouse Bay and Green Bay (Manukau Harbour), and hotpots for lichen species per site at Long Bay and Murrays Bay on the north-eastern coastline of Auckland. Sites in coastal locations are more similar to each other in terms of lichen community composition than they are to inland sites located a comparable distance away. These are all coastal sites with existing naturally occurring pōhutukawa forest, and some of the trees that were sampled are likely to be naturally occurring rather than planted. Inland sites tended to have lower numbers of lichen species, and lower numbers of species per tree, with the Waiatarua site standing out as a cold spot for both measures. Overall, the average number of lichen species per tree was negatively correlated with distance from the coast and distance from original forest. This indicates that while pōhutukawa as a species is able to grow well at inland sites (and can grow to a large size), the characteristic lichen flora may be more sensitive to, and reliant on, coastal microclimates where humid conditions are more prevalent $[6,48]$. 
However, proximity to existing coastal forest (and lichen propagules) may also be a factor in both the number of species per tree and number of species per site. Sites 8, 9, 10, 11, 12, 17, 18 and 20 are adjacent to original forest areas classified as WF4 (Coastal broadleaved forest), which are often dominated by pōhutukawa [66]. Site 13 is also located near an original forest, classified as SA1 (mangrove forest), while site 9 is located in both WF4 and SA1. As reported previously [6,48], there is a large degree of overlap between the lichen associates of mangrove and pōhutukawa forests. Lichens, as epiphytic organisms, are affected by isolation from other trees [67]; being closer to potential host trees facilitates the dispersal of the lichen species found.

The average number of lichen species per tree is positively correlated with DBH. This has been found in other studies $(6,4,15)$ and is usually attributed to habitat quantity and quality and a longer time for colonization if $\mathrm{DBH}$ is taken as a proxy for tree age. Not all sites with trees with high average DBH had more species per tree (e.g., Site 15, Cornwall Park), which supports the idea that distance from the coast may be more critical than tree size or age.

Vehicle traffic emits $\mathrm{NO}_{x}, \mathrm{CO}_{2}, \mathrm{CO}, \mathrm{SO}_{2}$ and particulates [35]. The effects of these pollutants on lichen survival and species distribution is complex. Acidic gaseous pollutants such as $\mathrm{SO}_{2}$ can reduce bark $\mathrm{pH}$, calcareous or other alkaline particulates can increase it, and the effect also varies by tree species [35]. Some lichen species are acidophytic, others are nitrophytic, and their presence or absence will be influenced by $\mathrm{pH}$ or environmental nitrogen availability. In addition, some gaseous pollutants $\left(\mathrm{NO}_{\mathrm{x}}\right.$ and $\left.\mathrm{SO}_{2}\right)$ are toxic in higher concentrations. For example, $\mathrm{NO}_{\mathrm{x}}$ is known to be phytotoxic when it exceeds $70 \mu \mathrm{g} / \mathrm{m}^{3}$, and $\mathrm{NO}_{2}$ when it exceeds $40 \mu \mathrm{g} / \mathrm{m}^{3}$ [68]. In our study, sulphur dioxide is unlikely to have affected patterns of lichen distribution because levels in the Auckland air have declined rapidly since the reduction in the sulphur content of vehicle fuels [69]. Nitrogen dioxide levels have also shown declines over the longer term, but recently some monitoring sites near major roads have repeatedly exceeded $40 \mu \mathrm{g} / \mathrm{m}^{3}$ [69]. In theory, pōhutukawa sites near major roads could be expected to be influenced by this. Our data showed a slight positive correlation between $\mathrm{NO}_{2}$ levels and average lichens per tree, but no apparent relationship with total lichens per site. There were no correlations with distance from major roads. One explanation for this lack of correlation is that some lichen species (e.g., Xanthoria parientina) are nitrophytic, and it is possible that higher urban nitrogen levels are in fact favouring the growth of these species at sites with higher $\mathrm{NO}_{2}$ levels $[26,27,70,71]$.

\section{Conclusions}

Colonisation of planted pōhutukawa trees by lichens appears to be limited by distance from a propagule source (original forest) and distance from the coast, indicating a need for a specific coastal microclimate. The correlation of average lichens per tree with $\mathrm{DBH}$ represents the quantity and quality of habitat available for lichen colonization, but also time for lichen propagules to arrive, as large trees tend to be older. At inland sites, most of the lichen species were common photophilous taxa that are found on a range of native and exotic tree phorophytes. More specialized uncommon species were largely restricted to coastal sites. This suggests that planting pōhutukawa trees at inland restoration sites, parks and reserves is not specifically contributing to the restoration of the pōhutukawa lichen mycobiota, but is instead providing habitat for common urban lichen species.

Author Contributions: Conceptualization, G.N.B. and D.B.; methodology, G.D.A. and D.B.; software, G.D.A.; validation, D.B.; formal analysis, G.D.A.; investigation, G.N.B.; resources, D.B.; data curation, G.D.A.; writing—original draft preparation, G.N.B. and G.D.A.; writing—review and editing, D.B. and G.D.A.; visualization, G.D.A.; funding acquisition, G.N.B. All authors have read and agreed to the published version of the manuscript.

Funding: This research supported in part through the travel grant of Gladys Benitez from the Royal Society of New Zealand and the National Science Foundation. 
Institutional Review Board Statement: Not applicable.

Data Availability Statement: The data presented in this study are available in this study.

Acknowledgments: We thank Unitec Institute of Technology for the use of vehicles, computers and laboratory space.

Conflicts of Interest: The authors declare no conflict of interest.

\section{References}

1. Lewis, J.E.J.; Ellis, C.J. Taxon-Compared with Trait-Based Analysis of Epiphytes, and the Role of Tree Species and Tree Age in Community Composition. Plant Ecol. Divers. 2010, 3, 203-210. [CrossRef]

2. Ellis, C.J. Lichen Epiphyte Diversity: A Species, Community and Trait-Based Review. Perspect. Plant Ecol. Evol. Syst. 2012, 14, 131-152. [CrossRef]

3. Hurtado, P.; Prieto, M.; Martínez-Vilalta, J.; Giordani, P.; Aragón, G.; López-Angulo, J.; Košuthová, A.; Merinero, S.; Díaz-Peña, E.M.; Rosas, T.; et al. Disentangling Functional Trait Variation and Covariation in Epiphytic Lichens along a Continent-Wide Latitudinal Gradient. Proc. R. Soc. B Biol. Sci. 2020, 287, 20192862. [CrossRef]

4. Aragón, G.; López, R.; Martínez, I. Effects of Mediterranean Dehesa Management on Epiphytic Lichens. Sci. Total Environ. 2010, 409, 116-122. [CrossRef] [PubMed]

5. Prieto, M.; Martínez, I.; Aragón, G.; Verdú, M. Phylogenetic and Functional Structure of Lichen Communities under Contrasting Environmental Conditions. J. Veg. Sci. 2017, 28, 871-881. [CrossRef]

6. Reynolds, C.L.; Er, O.A.H.; Winder, L.; Blanchon, D.J. Distribution and Community Composition of Lichens on Mature Mangroves (Avicennia marina Subsp. australasica (Walp.) J.Everett) in New Zealand. PLoS ONE 2017, 12, 0180525. [CrossRef]

7. Ranius, T.; Johansson, P.; Berg, N.; Niklasson, M. The Influence of Tree Age and Microhabitat Quality on the Occurrence of Crustose Lichens Associated with Old Oaks. J. Veg. Sci. 2008, 19, 653-662. [CrossRef]

8. Hilmo, O.; Holien, H.; Hytteborn, H.; Ely-aalstrup, H. Richness of Epiphytic Lichens in Differently Aged Picea Abies Plantations Situated in the Oceanic Region of Central Norway. Lichenologist 2009, 41, 97-108. [CrossRef]

9. Lie, M.H.; Arup, U.; Grytnes, J.-A.; Ohlson, M. The Importance of Host Tree Age, Size and Growth Rate as Determinants of Epiphytic Lichen Diversity in Boreal Spruce Forests. Biodivers. Conserv. 2009, 18, 3579-3596. [CrossRef]

10. Rosabal, D.; Burgaz, A.R.; Reyes, O.J. Substrate Preferences and Phorophyte Specificity of Corticolous Lichens on Five Tree Species of the Montane Rainforest of Gran Piedra, Santiago de Cuba. Bryologist 2013, 116, 113-121. [CrossRef]

11. Lamit, L.J.; Busby, P.E.; Lau, M.K.; Compson, Z.G.; Wojtowicz, T.; Keith, A.R.; Zinkgraf, M.S.; Schweitzer, J.A.; Shuster, S.M.; Gehring, C.A.; et al. Tree Genotype Mediates Covariance among Communities from Microbes to Lichens and Arthropods. J. Ecol. 2015, 103, 840-850. [CrossRef]

12. Wolseley, P.; Sanderson, N.; Thüs, H.; Carpenter, D.; Eggleton, P. Patterns and Drivers of Lichen Species Composition in a NW-European Lowland Deciduous Woodland Complex. Biodivers. Conserv. 2017, 26, 401-419. [CrossRef]

13. Calviño-Cancela, M.; Neumann, M.; López de Silanés, M.E. Contrasting Patterns of Lichen Abundance and Diversity in Eucalyptus globulus and Pinus pinaster Plantations with Tree Age. For. Ecol. Manag. 2020, 462, 117994. [CrossRef]

14. Łubek, A.; Kukwa, M.; Jaroszewicz, B.; Czortek, P. Identifying Mechanisms Shaping Lichen Functional Diversity in a Primeval Forest. For. Ecol. Manag. 2020, 475, 118434. [CrossRef]

15. Nascimbene, J.; Ackermann, S.; Dainese, M.; Garbarino, M.; Carrer, M. Fine-Scale Population Dynamics Help to Elucidate Community Assembly Patterns of Epiphytic Lichens in Alpine Forests. Fungal Ecol. 2016, 24, 21-26. [CrossRef]

16. Altman, J.; Doležal, J.; Čížek, L. Age Estimation of Large Trees: New Method Based on Partial Increment Core Tested on an Example of Veteran Oaks. For. Ecol. Manag. 2016, 380, 82-89. [CrossRef]

17. Johansson, P.; Rydin, H.; Thor, G. Tree Age Relationships with Epiphytic Lichen Diversity and Lichen Life History Traits on Ash in Southern Sweden. Ecoscience 2007, 14, 81-91. [CrossRef]

18. Coppins, A.M.; Coppins, B.J. Indices of Ecological Continuity for Woodland Epiphytic Lichen Habitats in the British Isles; British Lichen Society: London, UK, 2002.

19. Lidén, M.; Pettersson, M.; Bergsten, U.; Lundmark, T. Artificial Dispersal of Endangered Epiphytic Lichens: A Tool for Conservation in Boreal Forest Landscapes. Biol. Conserv. 2004, 118, 431-442. [CrossRef]

20. Brooker, R.W.; Brewer, M.J.; Britton, A.J.; Eastwood, A.; Ellis, C.; Gimona, A.; Poggio, L.; Genney, D.R. Tiny Niches and Translocations: The Challenge of Identifying Suitable Recipient Sites for Small and Immobile Species. J. Appl. Ecol. 2018, 55, 621-630. [CrossRef]

21. Smith, P.L. Lichen Translocation with Reference to Species Conservation and Habitat Restoration. Symbiosis 2014, 62, 17-28. [CrossRef]

22. Fritz, Ö.; Gustafsson, L.; Larsson, K. Does Forest Continuity Matter in Conservation?-A Study of Epiphytic Lichens and Bryophytes in Beech Forests of Southern Sweden. Biol. Conserv. 2008, 141, 655-668. [CrossRef]

23. Käffer, M.I.; Ganade, G.; Marcelli, M.P. Lichen Diversity and Composition in Araucaria Forests and Tree Monocultures in Southern Brazil. Biodivers. Conserv. 2009, 18, 3543-3561. [CrossRef]

24. Prather, H.M.; Eppley, S.M.; Rosenstiel, T.N. Urban Forested Parks and Tall Tree Canopies Contribute to Macrolichen Epiphyte Biodiversity in Urban Landscapes. Urban For. Urban Green. 2018, 32, 133-142. [CrossRef] 
25. Nash, T.H.; Gries, C. Lichens as Indicators of Air Pollution; Springer: Berlin/Heidelberg, Germany, 1991; pp. 1-29. [CrossRef]

26. Wolseley, P.A.; James, P.W.; Theobald, M.R.; Sutton, M.A. Detecting Changes in Epiphytic Lichen Communities at Sites Affected by Atmospheric Ammonia from Agricultural Sources. Lichenologist 2006, 38, 161-176. [CrossRef]

27. Kowarik, I.; Hiller, A.; Planchuelo, G.; Seitz, B.; von der Lippe, M.; Buchholz, S. Emerging Urban Forests: Opportunities for Promoting the Wild Side of the Urban Green Infrastructure. Sustainability 2019, 11, 6318. [CrossRef]

28. Zipper, S.C.; Schatz, J.; Singh, A.; Kucharik, C.J.; Townsend, P.A.; Loheide, S.P. Urban Heat Island Impacts on Plant Phenology: Intra-Urban Variability and Response to Land Cover. Environ. Res. Lett. 2016, 11, 054023. [CrossRef]

29. Parra-Sanchez, E.; Banks-Leite, C. The Magnitude and Extent of Edge Effects on Vascular Epiphytes across the Brazilian Atlantic Forest. Sci. Rep. 2020, 10, 1-11. [CrossRef] [PubMed]

30. Hamberg, L.; Lehvävirta, S.; Kotze, D.J. Forest Edge Structure as a Shaping Factor of Understorey Vegetation in Urban Forests in Finland. For. Ecol. Manag. 2009, 257, 712-722. [CrossRef]

31. Dislich, R.; Mantovani, W. Vascular Epiphyte Assemblages in a Brazilian Atlantic Forest Fragment: Investigating the Effect of Host Tree Features. Plant Ecol. 2016, 217, 1-12. [CrossRef]

32. McDonald, L.; van Woudenberg, M.; Dorin, B.; Adcock, A.M.; McMullin, R.T.; Cottenie, K. The Effects of Bark Quality on Corticolous Lichen Community Composition in Urban Parks of Southern Ontario. Botany 2017, 95, 1141-1149. [CrossRef]

33. Pescott, O.L.; Simkin, J.M.; August, T.A.; Randle, Z.; Dore, A.J.; Botham, M.S. Air Pollution and Its Effects on Lichens, Bryophytes, and Lichen-Feeding Lepidoptera: Review and Evidence from Biological Records. Biol. J. Linn. Soc. 2015, 115, 611-635. [CrossRef]

34. Llop, E.; Pinho, P.; Matos, P.; Pereira, M.J.; Branquinho, C. The Use of Lichen Functional Groups as Indicators of Air Quality in a Mediterranean Urban Environment. Ecol. Indic. 2012, 13, 215-221. [CrossRef]

35. Marmor, L.; Randlane, T. Effects of Road Traffic on Bark PH and Epiphytic Lichens in Tallinn I Folia Cryptogamica Estonica. Folia Cryptogam. Est. 2007, 43, 23-37.

36. Standish, R.J.; Hobbs, R.J.; Miller, J.R. Improving City Life: Options for Ecological Restoration in Urban Landscapes and How These Might Influence Interactions between People and Nature. Landsc. Ecol. 2013, 28, 1213-1221. [CrossRef]

37. McPhearson, P.; Feller, M.; Felson, A.; Karty, R.; Lu, J.; Palmer, M.; Wenskus, T. Assessing the Effects of the Urban Forest Restoration Effort of MillionTreesNYC on the Structure and Functioning of New York City Ecosystems. Cities Environ. 2011, 3, 7.

38. Wallace, K.J.; Laughlin, D.C.; Clarkson, B.D. Exotic Weeds and Fluctuating Microclimate Can Constrain Native Plant Regeneration in Urban Forest Restoration. Ecol. Appl. 2017, 27, 1268-1279. [CrossRef] [PubMed]

39. Belinchón, R.; Harrison, P.J.; Mair, L.; Várkonyi, G.; Snäll, T. Local Epiphyte Establishment and Future Metapopulation Dynamics in Landscapes with Different Spatiotemporal Properties. Ecology 2017, 98, 741-750. [CrossRef] [PubMed]

40. Zhao, D.; Sun, Z.; Wang, C.; Hao, Z.; Sun, B.; Zuo, Q.; Zhang, C.; Sun, R.; Jin, J.; Wang, H. Urban Orchards Provide a Suitable Habitat for Epiphytic Bryophytes. For. Ecol. Manag. 2021, 483, 118767. [CrossRef]

41. Ewers, R.M.; Kliskey, A.D.; Walker, S.; Rutledge, D.; Harding, J.S.; Didham, R.K. Past and Future Trajectories of Forest Loss in New Zealand. Biol. Conserv. 2006, 133, 312-325. [CrossRef]

42. Sullivan, J.; Meurk, C.; Whaley, K.; Simcock, R. Restoring Native Ecosystems in Urban Auckland: Urban Soils, Isolation, and Weeds as Impediments to Forest Establishment. N. Z. J. Ecol. 2009, 33, 60-71.

43. Auckland Council. Auckland's Urban Ngahere (Forest) Strategy. Available online: https://www.aucklandcouncil.govt.nz/plansprojects-policies-reports-bylaws/our-plans-strategies/topic-based-plans-strategies/environmental-plans-strategies/Pages / urban-ngahere-forest-strategy.aspx (accessed on 20 January 2021).

44. Esler, A.E. Changes in the Native Plant Cover of Urban Auckland, New Zealand. N. Z. J. Bot. 1991, 29, 177-196. [CrossRef]

45. Smale, M.C.; Gardner, O.R. Survival of Mount Eden Bush, an Urban Forest Remnant in Auckland, New Zealand. Pac. Conserv. Biol. 1999, 5, 83. [CrossRef]

46. De Lange, P.; Galloway, D.; Blanchon, D.; Knight, A.; Rolfe, J.; Crowcroft, G.; Hitchmough, R. Conservation Status of New Zealand Lichens. N. Z. J. Bot. 2012, 50, 303-363. [CrossRef]

47. Leddy, N.; Blanchon, D.J.; Wiapo, C.; Eruera, T.; Cameron, K.E.; Kahui-McConnell, R. Artificial Dispersal of the Lichen Crocodia aurata (Lobariaceae) Using Asexual Propagules and Gel-filled Gauze Packets. Ecol. Manag. Restor. 2019, 20, 119-125. [CrossRef]

48. Blanchon, D.J.; Ranatunga, D.; Marshall, A.J.; de Lange, P.J. Ecological Communities of Tree Species Threatened by Myrtle Rust (Austropuccinia psidii (G. Winter) Beenken): The Lichenised Mycobiota of Pōhutukawa (Metrosideros excelsa Sol. Ex Gaertn., Myrtaceae). Perspect. Biosecur. 2020, 5, 23-44.

49. De Lange, P.; Blanchon, D.; Knight, A.; Elix, J.; Lücking, R.; Frogley, K.; Harris, A.; Cooper, J.; Rolfe, J. Conservation Status of New Zealand Indigenous Lichens and Lichenicolous Fungi; Department of Conservation: Wellington, New Zealand, 2018.

50. Toome-Heller, M.; Ho, W.W.H.; Ganley, R.J.; Elliott, C.E.A.; Quinn, B.; Pearson, H.G.; Alexander, B.J.R. Chasing Myrtle Rust in New Zealand: Host Range and Distribution over the First Year after Invasion. Australas. Plant Pathol. 2020, 49, 221-230. [CrossRef]

51. Hayward, B.W.; Hayward, G.C.; Galloway, D.J. Lichens of Great Barrier and Adjacent Islands, Northern New Zealand. J. R. Soc. N. Z. 1986, 16, 121-137. [CrossRef]

52. Gadsdon, S.R.; Dagley, J.R.; Wolseley, P.A.; Power, S.A. Relationships between Lichen Community Composition and Concentrations of $\mathrm{NO}_{2}$ and $\mathrm{NH}_{3}$. Environ. Pollut. 2010, 158, 2553-2560. [CrossRef] [PubMed] 
53. NZTA. Nitrogen Dioxide Concentrations: New Zealand Transport Agency Data, 2010-16_Environmental Reporting GIS Map Data MfE Data Service. Available online: https:/ / data.mfe.govt.nz/table/98426-nitrogen-dioxide-concentrations-new-zealandtransport-agency-data-201016/ (accessed on 25 January 2021).

54. NZTA. Ambient Air Quality (Nitrogen Dioxide) Monitoring Programme-Operating Manual; 2017/18; NZTA: Wellington, New Zealand, 2017; Volume 3.

55. ESRI. Available online: http://desktop.arcgis.com/en/arcmap/ (accessed on 10 November 2018).

56. ESRI. How Hot Spot Analysis (Getis-Ord Gi *). Available online: http://pro.arcgis.com/en/pro-app/tool-reference/spatialstatistics/h-how-hot-spot-analysis-getis-ord-gi-spatial-stati.htm (accessed on 9 November 2018).

57. Getis, A.; Ord, J.K. The Analysis of Spatial Association by Use of Distance Statistics. In Perspectives on Spatial Data Analysis; Springer: Berlin/Heidelberg, Germany, 2010; pp. 127-145.

58. Ord, J.K.; Getis, A. Local Spatial Autocorrelation Statistics: Distributional Issues and an Application. Geogr. Anal. 1995, 27, 286-306. [CrossRef]

59. Anselin, L. Local Indicators of Spatial Association-LISA. Geogr. Anal. 1995, 27, 93-115. [CrossRef]

60. ESRI. How Cluster and Outlier Analysis (Anselin Local Moran's I). Available online: http:/ / pro.arcgis.com/en/pro-app/toolreference/spatial-statistics/h-how-cluster-and-outlier-analysis-anselin-local-m.htm (accessed on 12 November 2018).

61. Hannah, L.; Aguilar, G.; Blanchon, D. Spatial Distribution of the Mexican Daisy Erigeron karvinskianus, in New Zealand under Climate Change. Climate 2019, 7, 24. [CrossRef]

62. Aguilar, G.D.; Blanchon, D.J.; Foote, H.; Pollonais, C.W.; Mosee, A.N. A Performance Based Consensus Approach for Predicting Spatial Extent of the Chinese Windmill Palm (Trachycarpus fortunei) in New Zealand under Climate Change. Ecol. Inform. 2017, 39, 130-139. [CrossRef]

63. Sanders, L.J.; Aguilar, G.D.; Bacon, C.J. A Spatial Analysis of the Geographic Distribution of Musculoskeletal and General Practice Healthcare Clinics in Auckland, New Zealand. Appl. Geogr. 2013, 44. [CrossRef]

64. ESRI. Ordinary Least Squares (OLS)-Help Documentation. Available online: https://desktop.arcgis.com/en/arcmap/10.7 /tools/spatial-statistics-toolbox/ordinary-least-squares.htm (accessed on 9 January 2020).

65. González-Maya, J.F.; Víquez-R, L.R.; Arias-Alzate, A.; Belant, J.L.; Ceballos, G. Spatial Patterns of Species Richness and Functional Diversity in Costa Rican Terrestrial Mammals: Implications for Conservation. Divers. Distrib. 2016, 22, 43-56. [CrossRef]

66. Singers, N.J.D.; Rogers, G.M. A Classification of New Zealand's Terrestrial Ecosystems; Department of Conversation: Wellington, New Zealand, 2014.

67. Kiebacher, T.; Keller, C.; Scheidegger, C.; Bergamini, A. Epiphytes in Wooded Pastures: Isolation Matters for Lichen but Not for Bryophyte Species Richness. PLoS ONE 2017, 12, 0182065. [CrossRef] [PubMed]

68. Davies, L.; Bates, J.W.; Bell, J.N.B.; James, P.W.; Purvis, O.W. Diversity and Sensitivity of Epiphytes to Oxides of Nitrogen in London. Environ. Pollut. 2007, 146, 299-310. [CrossRef]

69. Talbot, N.; Crimmins, P. Air Quality in Auckland: In-Depth Trend Analysis Technical Report 2020/004; Auckland Council: Auckland, New Zealand, 2020.

70. Van Herk, C.M.; Mathijssen-Spiekman, E.A.M.; de Zwart, D. Long Distance Nitrogen Air Pollution Effects on Lichens in Europe. Lichenologist 2003, 35, 347-359. [CrossRef]

71. Wolseley, P.A.; Stofer, S.; Mitchell, R.; Truscott, A.-M.; Vanbergen, A.; Chimonides, J.; Scheidegger, C. Variation of Lichen Communities with Landuse in Aberdeenshire, UK. Lichenologist 2006, 38, 307-322. [CrossRef] 